\title{
Antifouling Paints Biocides (Irgarol 1051 and Diuron) in the Selected Ports of Peninsular Malaysia: Occurrence, Seasonal Variation and Ecological Risk Assessment.
}

\author{
Hassan Rashid Ali \\ The State University of Zanzibar \\ Marinah Mohd Ariffin ( $\square$ erin@umt.edu.my) \\ Universiti Malaysia Terengganu \\ Tuan Fauzan Tuan Omar \\ Universiti Malaysia Terengganu \\ Adiana Ghazali \\ Universiti Malaysia Terengganu \\ Mohammed Ali Sheikh \\ The State University of Zanzibar \\ Noor Azhar Mohamed Shazili \\ Universiti Malaysia Terengganu \\ Zainudin Bachok \\ Universiti Malaysia Terengganu
}

\section{Research Article}

Keywords: Antifouling biocides, Diuron, Irgarol, ecological risk assessment, seasonal distribution

Posted Date: March 10th, 2021

DOI: https://doi.org/10.21203/rs.3.rs-269864/v1

License: (c) (i) This work is licensed under a Creative Commons Attribution 4.0 International License. Read Full License 


\begin{abstract}
Irgarol and Diuron are photosystem II inhibitor in agricultural activities and antifouling paint in shipping sector. A study took place at three major ports surround the Peninsular Malaysia was carried out to construct the distribution of both biocides based on the seasonal and geographical changes. Surface seawater samples were collected during November 2011 to April 2012; pretreated using solid phase extraction technique followed by quantification with GC-MS and LC-MS-MS for Irgarol and Diuron, respectively. Generally, the distribution of Irgarol was lowest during November 2011 and highest during April 2012, which is similar pattern was observed at all ports, whereas the distribution of Diuron was rather vague. The increasing pattern of Irgarol from time to time is probably related to its accumulation in the seawater due to the half-life and consistent utilization. Based on the discriminant analysis, the temporal distribution of Irgarol varied at Klang North Port, Klang South Port and Pasir Gudang Port, whereas Diuron was temporally varied only at Kemaman Port. Furthermore, Irgarol was spatially varied during November 2011, whereas Diuron did not show any significant changes throughout all sampling periods. Ecological risk assessment exhibited high risk for Diuron and Irgarol, but however Irgarol should be of concern due to it relatively higher risk as compared to Diuron. Thus, it is recommended that the current Malaysian guideline and regulation of biocides application should be reevaluated and improve to protect the ecosystem, as well as preventing ecological risk to the aquatic environment.
\end{abstract}

\title{
1. Introduction
}

Marine biofoulings are organisms which are colonize on the submerged structures such as ship's hull, oil rig stand and fish cage (Shevalkar et al. 2020). The colonization of these organisms poses severe concern, especially to the shipping industry. The biofoulings frequently increase fuel consumption of the ship since the attachment increase the hull's friction, therefore extra fuel is needed to maintain the normal ship's speed (Abbott et al. 2000; Evans et al. 2000). Besides that, attachment of the biofouling also put extra cost in maintaining the ship's hull as they need to be clean up periodically in a year. Due to this concern, the usage of antifouling coating paints has been widely used to incapacitate the marine biofouling in improving the shipping industry.

Antifouling paint is a coating paint which is frequently applied on the underwater hulls to inhibit or slower the growth as well as detach the marine biofoulings from the submerged structures. Historically, numerous types of chemicals such as organotin (OT) compounds, organomercury compounds and DDT has been widely used as antifouling in underwater coating paints. Nonetheless, such compounds cause deleterious effects to the environment and human health; therefore, they were banned in shipping industrial sector and were replaced by organotin (OT) compounds such as tributyltin and triphenyltin (Mukhtar et al. 2019). Yet to be resolved, in the early of 21 st century, after being used as antifouling paint, OT compounds has been also banned due to its acute toxicity, persistency and poorly biodegradable (Macken et al. 2008; Kucuksezgin et al. 2011; Tsunemasa and Okamura 2011).

The banned of OT compounds as antifouling paints has turn to call for biocides compounds as alternative antifouling agent in coating paint (Hanapiah et al. 2017). The selection of biocides booster is due to less persistent and highly degradable characteristics (Mukhtar et al. 2019). Biocides are chemical compounds or microorganisms that are being used to kill, prevent, or harm to any harmful entity or pests. The most common biocides booster which has been widely used in antifouling paint is Irgarol and Diuron. Both biocides are extensively being used in agricultural activities as photosystem II inhibitor herbicides (Girling et al. 2015). According to Dafforn et al. (2011), the half-life for Irgarol and Diuron is in the range of 100 to 350 days and 1 to 12 months, respectively. Conversely, both biocides also pose some threat to the non-targeted organisms such as benthic organisms and seagrass (Magnuson et al. 2013; Fernandez and Gardinali 2016; Koanga et al. 2016).

In Malaysia, the usage of Irgarol and Diuron is knowingly being utilized in both shipping and agricultural activities. The present study is performed to investigate the influence of seasonal and geographical changes on the distribution of both biocides in the seawater, as well as evaluation on the ecological risk. Three out of seven major ports surround Peninsular Malaysia has been selected. The selected ports are Kemaman Port, Pasir Gudang Port and Klang ports, represent the east, south, and west part of Peninsular Malaysia, respectively.

\section{Materials And Methods}

\subsection{Sample collection}

Surface seawater samples were collected during November 2011, January 2012, and April 2012 at three major ports in Peninsular Malaysia. The selected ports are Kemaman Port, Pasir Gudang Port and Klang Port (Fig. 1). The Klang Port is separated into three sub-ports which are North Klang Port, South Klang Port and West Klang Port. Seawater samples were collected into a clean acetone-washed amber bottle and kept under lowest temperature in an ice box, prior transportation to the laboratory.

\subsection{Analytical procedure and chromatographic analysis}


Solid phase extraction (SPE) technique was used to extract Irgarol from water samples. Extraction procedure was previously described by Sheikh et al. (2009) and Ali et al. (2015). In brief, Isolute Triazine SPE cartridges conditioning was carried out by eluting $10 \mathrm{ml}$ of methanol followed by $10 \mathrm{~mL}$ of ultrapure water (UPW). Seawater samples were loaded into SPE cartridge at constant flow rate (20 $\mathrm{mL} / \mathrm{min})$. The cartridges were subjected for washing using $10 \mathrm{~mL}$ of UPW and subsequently dried under vacuum for 45 min before eluting with $5 \mathrm{~mL}$ of ethyl acetate: acetone (1:1) through anhydrous sodium sulphate column. Internal standard, $p$-terphenyl- $\mathrm{d}_{14}(200 \mu \mathrm{L}$ of $50 \mu \mathrm{g} / \mathrm{L}) \mathrm{was}$ added into the extracts before the combined extract was blow down using Nitrogen gas to about $200 \mu \mathrm{L}$. The final extracts were analysed using Gas Chromatography - Mass Spectrometry, QP 2010 (Shimadzu, Japan). Separation of the targeted analyte was accomplished using DB-5 MS capillary column. The GC MS setting such as injection temperature, column oven temperature, temperature program, ion source temperature and, etc. were previously described in Ali et al. (2015).

Diuron in the other hand was pre-concentrated using PLS-3 SPE cartridge column, as adapted from Sheikh et al. (2009). The cartridge was first conditioned using acetonitrile, methanol and milli-Q water, in respective order. Prior to loading, the $\mathrm{pH}$ of $1 \mathrm{~L}$ of water samples was maintained at 3.5 by adding $10 \mathrm{~mL} 0.2 \mathrm{M}$ EDTA followed by $1 \mathrm{~mL}$ of $1 \mathrm{mg} / \mathrm{L}$ Diuron D- $6\left(\mathrm{C}_{9} \mathrm{H}_{4} \mathrm{Cl}_{2} \mathrm{D}_{6} \mathrm{~N}_{2} \mathrm{O}\right)$ was also added as surrogate standard. The analysis of Diuron was carried out using by LC-MS/MS with Agilent ZORBAX Eclipse XDB-C18 column, as described by Ali et al. (2014). Overall, analytical method showed good precision and sensitivity with average percentage recoveries for both Diuron and Irgarol were more than $90 \%$, with detection limits $0.5 \mathrm{ng} / \mathrm{L}$ and $1.0 \mathrm{ng} / \mathrm{L}$, respectively.

\subsection{Statistical analysis}

Discriminant analysis (DA) is a statistical approach which has been widely used to classify a set of observed data into pre-defined classes. It is commonly utilized to discriminate the variables between two or more sample groups (Adiana et al. 2017). In the present study, DA was applied to raw dataset by using standard, stepwise forward and stepwise backward methods to construct discriminant functions (DFA) for spatial and temporal variations of biocides in the water column of major ports in Peninsular Malaysia. DA was carried out using XLSTAT 2014.5.03 software. In the stepwise forward mode, the variable is introduced step-by-step from the most significant until no significant changes are obtained; meanwhile in the stepwise backward, the variable is removed step-by-step with the least significant variable until no significant changes is obtained (Chabukdhara and Nema 2012; Juahir et al. 2019).

\subsection{Ecological risk assessment}

Ecological risk assessment was calculated based on procedure described in European Chemicals Agency (ECHA, 2017) and as well as referring to Technical Guidance Document on Risk Assessment (TGD) (European Commission 2003). The calculation of risk factor or also known as risk quotient (RQ) is following formula in Eq. 1:

$\mathrm{RQ}=\frac{\mathrm{MEC}}{\mathrm{PNEC}}$

where, MEC is a measured concentration of biocides in the surface water, while PNEC is predicted no effect concentration of biocides in the ecosystem. The PNEC values were obtained from ecotoxicity endpoint (LC50/EC50) of chemicals for the respective species in the relevant environment and using appropriate assessment factor as outlined in the TGD guideline. The calculation for PNEC is described in the following Eq. 2:

PNEC $=\frac{\text { LC50 or EC50 }}{1000}$

Three standard test species which were algae, daphnids and fish, corresponding to three different trophic levels were evaluated. The ecotoxicity endpoint of selected biocides for those three test species were obtained from ECOSAR database (USEPA, 2011). The risk was classified into four: negligible risk $(R Q<0.01$, low risk $(0.01 \leq R Q<0.1)$, medium risk $(0.1 \leq R Q<1)$, and high risk $(R Q>1)(P a l m a$ et al. 2014$)$.

\section{Results And Discussion}

Generally, the average distribution of Irgarol and Diuron in seawater, collected at the major ports of Peninsular Malaysia is shown in Fig. 2. Throughout November 2011, January 2012, and April 2012; the distribution of Irgarol shows similar increasing pattern at all ports, where the concentration of Irgarol was the lowest in November 2011 and highest in April 2012. However, the distribution of Diuron was undistinguishable, where each port has recorded different period with high and low concentration of Diuron.

The distribution pattern of Irgarol is proclaimed by the consistently usage of Irgarol as the antifouling biocides at the selected major ports in Peninsular Malaysia, with no additional source. Irgarol is a notable alternative tributyltin-free vessel coating paint which has been used widely since the usage of tributyltin coating was banned due to its severe impact towards the ecosystem (Konstantinou and Albanis 2004; Ali et al. 
2015; Gallucci et al. 2015). Additionally, the continuing pattern of Irgarol in the seawater samples indicated the accumulation of Irgarol compound correlated with its' half-life cycle. According to Dafforn et al. (2011) and Galucci et al. (2015), since the half-life for Irgarol in the seawater is in between 100 to 350 days, it is not simply degraded in a short period of time. In the present study, the gap left between the sampling periods was approximately two months apart, i.e., 60 days. Ideally, the Irgarol compound which has been introduced during November 2011 did not completely degraded in the seawater; however, the continuous usage of Irgarol by the boats and vessel coating activities are introducing additional Irgarol into the water column. Therefore, the concentration of Irgarol constantly accumulates in time which explains the increasing trend of Irgarol in the collected seawater at the major ports in Peninsular Malaysia.

In the meantime, the existent of Diuron in the seawater is less persistent than Irgarol (Thomas et al. 2002) which may justify the vague distribution of Diuron recorded throughout the study period. Based on Fig. 2, the average concentration of Diuron recorded in Kemaman Port and Pasir Gudang Port were slightly lower than recorded in Klang ports (Klang North Port, Klang South Port and Klang West Port). The random distribution of Diuron in the collected seawater samples is deemed to be affected by the usage of antifouling paint contains biocides booster at the ports as well as continuous usage of Diuron in agricultural activities. A similar finding was found by Omar et al. (2018) as the possible source of organic pollutants found within Klang ports region were derived by high industrial and agricultural activities surround.

On-site observation during sampling activities found that Kemaman Port is largely surrounded by urbanisation and industrial activities; Pasir Gudang Port is located within the vicinity of high industrial and urban activities, whereas Klang ports are predominantly enclosed by high industrial, agricultural and urbanisation activities. According to Rameli and Jaafar (2014), large area of southwest Selangor which include Carey Island, Morib and Tanjong Sepat are dominantly being occupied by palm oil plantation. Therefore, this activity is counted as a non-point source of Diuron which has been contaminating the water column of Klang ports since Diuron is being actively used as herbicides in agricultural activies (Ali et al. 2014); besides the continuous usage of Diuron as antifouling biocides paints in shipping sector (Ansanelli et al. 2017; Hanapiah et al. 2017).

The variation of Irgarol and Diuron throughout the present study was further investigated using discriminant analysis (DA). DA was applied on the raw dataset for both biocides using standard, stepwise forward and stepwise backward methods. The spatial variation of Irgarol using standard mode DFA (Table 1) shows an accuracy of $50 \%$ with 1 discriminant variable whereas the accuracy of Irgarol spatial variation using stepwise forward and stepwise backward mode DFA is similar which is $42.86 \%$ with 1 discriminant variable. The only significant discriminant variable for all DA modes is sampling period of November 2011 which explain the variation of Irgarol was significant between sampling area during November 2011. The spatial distribution of Irgarol during November 2011 sampling period shows a significant variation compared to January 2012 and April 2012 sampling period (Fig. 3).

Table 1

Classification matrix for Irgarol spatial distribution using DA.

\begin{tabular}{|c|c|c|c|c|c|c|c|}
\hline \multicolumn{8}{|c|}{ Standard DA Mode (1 variable) } \\
\hline Sampling Area & Kemaman & $\begin{array}{l}\text { Klang North } \\
\text { Port }\end{array}$ & $\begin{array}{l}\text { Klang South } \\
\text { Port }\end{array}$ & $\begin{array}{l}\text { Klang West } \\
\text { Port }\end{array}$ & $\begin{array}{l}\text { Pasir Gudang Johor } \\
\text { Port }\end{array}$ & Total & $\begin{array}{l}\% \\
\text { correct }\end{array}$ \\
\hline Kemaman & 3 & 1 & 0 & 0 & 1 & 5 & 60.00 \\
\hline Klang North Port & 2 & 1 & 0 & 0 & 2 & 5 & 20.00 \\
\hline Klang South Port & 1 & 0 & 0 & 0 & 4 & 5 & 0.00 \\
\hline Klang West Port & 0 & 0 & 0 & 3 & 2 & 5 & 60.00 \\
\hline $\begin{array}{l}\text { Pasir Gudang Johor } \\
\text { Port }\end{array}$ & 0 & 0 & 0 & 1 & 7 & 8 & 87.50 \\
\hline Total & 6 & 2 & 0 & 4 & 16 & 28 & 50.00 \\
\hline \multicolumn{8}{|c|}{ Stepwise Forward DA and Stepwise Backward DA Mode (1 variable) } \\
\hline Kemaman & 4 & 0 & 0 & 0 & 1 & 5 & 80.00 \\
\hline Klang North Port & 2 & 0 & 0 & 0 & 3 & 5 & 0.00 \\
\hline Klang South Port & 1 & 0 & 0 & 0 & 4 & 5 & 0.00 \\
\hline Klang West Port & 0 & 1 & 0 & 0 & 4 & 5 & 0.00 \\
\hline $\begin{array}{l}\text { Pasir Gudang Johor } \\
\text { Port }\end{array}$ & 0 & 0 & 0 & 0 & 8 & 8 & 100.00 \\
\hline Total & 7 & 1 & 0 & 0 & 20 & 28 & 42.86 \\
\hline
\end{tabular}


Based on Table 2, the accuracy of Irgarol temporal classification using standard mode DFA is $93.33 \%$ (5 discriminant variables) whereas similar accuracy of temporal classification for stepwise forward and stepwise backward modes DFA is $80 \%$ (3 discriminant variables). Klang North Port (KNP), Klang South Port (KSP) and Pasir Gudang (PGJP) Johor Port were found to be the discriminant variables using the stepwise forward and stepwise backward DA methods. According to DA temporal variation, KNP, KSP and PGJP shows high variation of Irgarol compared to Kemaman and Klang West Port (Fig. 4).

Table 2

Classification matrix for Irgarol temporal distribution using DA.

\begin{tabular}{|c|c|c|c|c|c|}
\hline \multicolumn{6}{|c|}{ Standard DA Mode (5 variables) } \\
\hline Sampling Period & April, 2012 & January, 2012 & November, 2011 & Total & $\%$ correct \\
\hline April, 2012 & 5 & 0 & 0 & 5 & 100.00 \\
\hline January, 2012 & 0 & 4 & 1 & 5 & 80.00 \\
\hline November, 2011 & 0 & 0 & 5 & 5 & 100.00 \\
\hline Total & 5 & 4 & 6 & 15 & 93.33 \\
\hline \multicolumn{6}{|c|}{ Stepwise Forward DA and Stepwise Backward DA Mode (3 variables) } \\
\hline April, 2012 & 5 & 0 & 0 & 5 & 100.00 \\
\hline January, 2012 & 0 & 3 & 2 & 5 & 60.00 \\
\hline November, 2011 & 0 & 1 & 4 & 5 & 80.00 \\
\hline Total & 5 & 4 & 6 & 15 & 80.00 \\
\hline
\end{tabular}

The spatial variation of Diuron using standard mode DFA (Table 3 ) shows an accuracy of $50 \%$ with no discriminant variable, where there is no significant spatial distribution of Diuron throughout the present sampling period.

Table 3

Classification matrix for Diuron spatial distribution using DA.

\begin{tabular}{|c|c|c|c|c|c|c|c|}
\hline \multicolumn{8}{|c|}{ Standard DA Mode (No discriminant variable) } \\
\hline Sampling Area & Kemaman & $\begin{array}{l}\text { Klang North } \\
\text { Port }\end{array}$ & $\begin{array}{l}\text { Klang South } \\
\text { Port }\end{array}$ & $\begin{array}{l}\text { Klang West } \\
\text { Port }\end{array}$ & $\begin{array}{l}\text { Pasir Gudang Johor } \\
\text { Port }\end{array}$ & Total & $\begin{array}{l}\% \\
\text { correct }\end{array}$ \\
\hline Kemaman & 4 & 0 & 0 & 0 & 1 & 5 & 80.00 \\
\hline Klang North Port & 0 & 3 & 0 & 1 & 1 & 5 & 60.00 \\
\hline Klang South Port & 0 & 1 & 1 & 1 & 2 & 5 & 20.00 \\
\hline Klang West Port & 2 & 0 & 2 & 0 & 1 & 5 & 0.00 \\
\hline $\begin{array}{l}\text { Pasir Gudang Johor } \\
\text { Port }\end{array}$ & 2 & 0 & 0 & 0 & 6 & 8 & 75.00 \\
\hline Total & 8 & 4 & 3 & 2 & 11 & 28 & 50.00 \\
\hline
\end{tabular}

Based on Table 4, the accuracy of Diuron temporal classification using standard mode DFA is $58.33 \%$ (1 discriminant variable) whereas similar accuracy of Diuron temporal classification for stepwise forward and stepwise backward modes DFA is $54.17 \%$ (1 discriminant variable). DA temporal variation of Diuron shows that Kemaman sampling area is the only discriminant variable where the Diuron distribution was varied highly during the present sampling periods (Fig. 5). 
Table 4

Classification matrix for Diuron temporal distribution using DA.

\begin{tabular}{|c|c|c|c|c|c|}
\hline \multicolumn{6}{|c|}{ Standard Mode DA (1 variable) } \\
\hline Sampling Period & April, 2012 & January, 2012 & November, 2011 & Total & $\%$ correct \\
\hline April, 2012 & 5 & 0 & 3 & 8 & 62.50 \\
\hline January, 2012 & 1 & 5 & 2 & 8 & 62.50 \\
\hline November, 2011 & 1 & 3 & 4 & 8 & 50.00 \\
\hline Total & 7 & 8 & 9 & 24 & 58.33 \\
\hline \multicolumn{6}{|c|}{ Stepwise Forward and Stepwise Backward DA (1 variable) } \\
\hline April, 2012 & 8 & 0 & 0 & 8 & 100.00 \\
\hline January, 2012 & 3 & 4 & 1 & 8 & 50.00 \\
\hline November, 2011 & 5 & 2 & 1 & 8 & 12.50 \\
\hline Total & 16 & 6 & 2 & 24 & 54.17 \\
\hline
\end{tabular}

Risk assessment of pollutants in the environment have been widely applied to indicate the extent of contamination of various type of organic pollutants in the ecosystem, particularly in the aquatic compartment. The estimation of ecological risks for pesticides and other type of organic pollutants in Malaysian coastal water have been described by several studies, and it was observed that the risks are being categorized from negligible to high risk. For the record, in Klang estuary, pesticide such as chlorpyrifos has been classified as having a high risk (Wee and Aris 2017) while other organic pollutants such as pharmaceutically active compounds (PhACs) are classified as low risk (Omar et al. 2019). However, there were no previous studies have been reported on the ecological risk of Irgarol and Diuron in the aquatic environment of Malaysian coastal water, and thus the present assessment will be the first account of study reported on the risk of these biocides. As a chemical that are widely being used for marine application as well as agriculture sector, these biocides should be given specific attention due to toxicity of these chemical towards marine organisms in the aquatic food web.

Several toxicological studies have indicated that both biocides are the major threat to non-target organisms, such as coral reef and fishes, as well as other aquatic life. A study by Ali et al. (2015) reported toxicological evaluation of Irgarol on Asian seabass, Lates calcarifer, and found that this substance was toxic and reduced the fatty acid composition of the fish at the low level of concentration. Both compounds also showed toxic effects in marine microalgae species such as, Tisochrysis lutea, Skeletonema marinoi and Tetraselmis suecica (Dupraz et al. 2017). Another study by Park et al. (2016a) reported that exposure to Irgarol and Diuron have potential hazardous effect on Pacific oyster, Crassostrea gigas, while Park et al. (2016b) observed changes in the exoskeleton, molting, and proteolysis metabolism of mud crab, Macrophthalmus japonicus, when exposed to Irgarol.

Table 5 shows the ecotoxicity endpoint and risk quotient (RQ) of algae, daphnids and fish for Irgarol and Diuron in the surface water of selected ports in peninsular Malaysia. The calculated RQ for the three test species showed that algae posed high risk for both of Irgarol and Diuron during the present study, particularly during April 2012 sampling. Based on the maximum concentration from three sampling period, the value of RQ is 1.61 and 77.73 for Diuron and Irgarol, respectively. Irgarol was observed to exhibit higher risk as compared to Diuron at the ports of peninsular Malaysia. Throughout the sampling campaigns that were carried out for 2-3-month interval, the risk of Irgarol was significantly increased during April 2012 sampling.

Table 5

Ecotoxicity endpoints for algae, daphnids and fish and risk quotient (RQ) assessment for Diuron and Irgarol in surface water of selected ports in Peninsular Malaysia.

\begin{tabular}{|c|c|c|c|c|c|c|c|c|c|c|c|}
\hline \multirow[t]{2}{*}{ Compounds } & \multicolumn{3}{|c|}{ EC50/LC50 $\left(\mu \mathrm{g} \mathrm{L}^{-1}\right)$} & \multirow{2}{*}{$\begin{array}{l}\text { Assessment } \\
\text { factor }\end{array}$} & \multicolumn{3}{|c|}{ PNEC $\left(\mu \mathrm{g} \mathrm{L}^{-1}\right)$} & \multirow{2}{*}{$\begin{array}{l}\text { Concentration } \\
\left(\mu \mathrm{g} \mathrm{L}^{-1}\right) \\
\text { Maximum }\end{array}$} & \multicolumn{3}{|l|}{ RQ } \\
\hline & Fish & Daphnids & Algae & & Fish & Daphnids & Algae & & Fish & Daphnids & Algae \\
\hline Diuron & 18100 & 5220 & 177 & 1000 & 2.13 & 3.12 & 0.26 & 0.285 & 0.015 & 0.052 & 1.61 \\
\hline Irgarol & 2130 & 3120 & 26 & 1000 & 18.1 & 5.22 & 0.177 & 2.021 & 0.95 & 0.65 & 77.73 \\
\hline
\end{tabular}

EC50 = effective concentration; LC50 = lethal concentration; PNEC = predicted no effect concentration, RQ = risk quotient 
Table 6

Comparison of biocides (Irgarol and Diuron) in the surface water of selected ports in peninsular Malaysia relatives to other countries

\begin{tabular}{|c|c|c|c|c|c|c|c|c|}
\hline \multirow{2}{*}{$\begin{array}{l}\text { Location/ } \\
\text { Country }\end{array}$} & \multirow[t]{2}{*}{ Method } & \multicolumn{3}{|l|}{ Diuron } & \multicolumn{3}{|c|}{ Irgarol } & \multirow[t]{2}{*}{ References } \\
\hline & & $\begin{array}{l}\text { LOD } \\
\text { (ng L- } \\
\text { 1) }\end{array}$ & $\begin{array}{l}\text { Concentration }_{\max } \\
\left(\mu \mathrm{g} \mathrm{L}^{-1}\right)\end{array}$ & RQ & $\begin{array}{l}\text { LOD } \\
\text { (ng } \\
\mathrm{L}^{-} \\
\left.{ }^{1}\right)\end{array}$ & $\begin{array}{l}\text { Concentration }_{\max } \\
\left(\mu \mathrm{g} \mathrm{L}^{-1}\right)\end{array}$ & RQ & \\
\hline São Marcos Bay / Brazil & $\begin{array}{l}\text { SPE-LC } \\
\text { MS/MS }\end{array}$ & 0.8 & 0.022 & 14.7 & 1.4 & 0.089 & 37 & $\begin{array}{l}\text { Viana et } \\
\text { al., } 2020\end{array}$ \\
\hline Bay of Vilaine / Britanny, France & $\begin{array}{l}\text { SPE- } \\
\text { LCMS/MS }\end{array}$ & 50 & 0.268 & 5 & 20 & 0.186 & 100 & $\begin{array}{l}\text { Caquet et } \\
\text { al., } 2013\end{array}$ \\
\hline $\begin{array}{l}\text { River in southern Poland / } \\
\text { Poland }\end{array}$ & $\begin{array}{l}\text { SPE-GC } \\
\text { MS/MS }\end{array}$ & 2.5 & 0.077 & 0.39 & - & - & - & $\begin{array}{l}\text { Durak et } \\
\text { al., } 2021\end{array}$ \\
\hline $\begin{array}{l}\text { Kemaman, Klang and Pasir } \\
\text { Gudang ports / Malaysia }\end{array}$ & $\begin{array}{l}\text { SPE-GC } \\
\text { MS/MS }\end{array}$ & 0.5 & 0.285 & 1.61 & 1.0 & 2.021 & 77.73 & This study \\
\hline
\end{tabular}

Referring to Fig. 6, the RQ for Irgarol particularly for algae were categorised as high for all sampling points during the April 2012 sampling. As comparison with January 2012 and November 2011 sampling, only several sampling points indicated high risk of Irgarol, notably in Klang and Kemaman port. Meanwhile for Diuron, only two sampling points indicated high risk as shown in Pasir Gudang and Klang port during April 2012 and January 2012 sampling, respectively. It was noted that the concentration of Diuron at both sampling points during those sampling period exceeded the maximum level as stipulated in the Malaysian Marine Water Quality Standards (MMWQs) which is regulated at $0.2 \mu \mathrm{g} / \mathrm{L}$. However, the similar comparison cannot be made for Irgarol because there is no regulation yet for the allowable level of this biocide in the MMWQs. Thus, due to high risk, the need for guideline value for Irgarol to be included in the MMWQs should be taking into consideration as an effort to protect the aquatic and marine life.

Comparison of worldwide studies on the ecological risk assessment of Irgarol and Diuron showed similar trend of risk classification. As summarized in Table 6, most of studies reported high risk for Irgarol and Diuron in the aquatic ecosystem. High risk of Irgarol and Diuron was reported in the São Marcos Bay of Brazil (Viana et al. 2021), while similar risk trend was also reported in the Bay of Vilaine, France. Both locations exhibited the RQ more than 1 with the highest RQ of 100 was reported at Bay of Vilaine. Only a study in several river system in Poland showed the RQ for Diuron less than 1, which reported at 0.39 indicating moderate risk to the aquatic ecosystem. This trend of ecological risk suggested that most of the countries having a serious threat with the Irgarol and Diuron contamination, and therefore it should be considered as priority pollutants that must be continuously monitored.

\section{Conclusion}

The present study evaluated the status of biocides contamination in the surface water of major ports across Peninsular Malaysia. The ecological risk assessment was determined using deterministic approach, based on RQ method. Ecological risk estimation for the two types of commonly used biocides, Irgarol and Diuron, in the selected ports of Peninsular Malaysia revealed that more attention should be given to monitor these contaminants in various marine or ship related activities across Malaysia. As evidence from the present study, the occurrence and presence of Irgarol should be of concern due to it relatively higher risk as compared to Diuron. Even though in several sampling points, the level of Diuron exceeded the allowable limit of MMWQs and showed high risk in some location, but for overall this biocide can be regarded as safe during the present assessment. This risk assessment evaluation is an important step for preliminary risk screening of organic pollutants that can provide a basis for environmental management plan that can be useful for relevant authorities such environmental legislator and policy maker. This study will also provide information on risk prioritization which will set direction towards the protection and sustainability of marine ecosystem from harmful contaminants.

\section{Declarations}

\section{Ethics approval and consent to participate:}

Not applicable. 
Consent for publication:

Not applicable.

\section{Availability of data and materials:}

The datasets used / or analysed during the current study are available from the corresponding author on reasonable request.

\section{Competing interests:}

The authors declare that they have no competing interests.

\section{Funding:}

Fundamental Research Grant Scheme (FRGS/1/2011/STWN/UMT/02/3) by the Ministry of Education Malaysia (MOE) was used to fully fund this research (the design of study and collection, analysis, and interpretation of data).

\section{Author's Contributions:}

\begin{tabular}{|ll|}
\hline Contributions & Author \\
\hline Study conception and design & $\begin{array}{l}\text { Hassan Rashid Ali, Zainudin Bachok, Marinah Mohd Arifin, Noor Azhar Mohamed Shazili, Mohammed } \\
\text { Ali Sheikh }\end{array}$ \\
\hline $\begin{array}{l}\text { Writing - original draft } \\
\text { preparation }\end{array}$ & $\begin{array}{l}\text { Hassan Rashid Ali, Zainudin Bachok, Marinah Mohd Arifin, Noor Azhar Mohamed Shazili, Mohammed } \\
\text { Ali Sheikh }\end{array}$ \\
\hline Writing - review and editing & Marinah Mohd Arifin, Tuan Fauzan Tuan Omar, Adiana Ghazali \\
\hline Data analysis & Tuan Fauzan Tuan Omar, Adiana Ghazali \\
\hline Funding acquisition & Zainudin Bachok \\
\hline Supervision & Zainudin Bachok, Marinah Mohd Arifin, Noor Azhar Mohamed Shazili, Mohammed Ali Sheikh \\
\hline
\end{tabular}

\section{Acknowledgements:}

This research is funded by the Ministry of Education Malaysia (MOE) research grant Fundamental Research Grant Scheme (FRGS/1/2011/STWN/UMT/02/3). The authors would like to acknowledge University of Malaysia Terengganu (UMT), especial to Institute of Oceanography and Environment (INOS), Faculty of Science and Marine Environment (FSSM), and the State University of Zanzibar (SUZA) for their support in conducting this research.

\section{References}

1. Abbot, A., Abel, P. D., Arnold, D. W. and Milne, A. 2000. Cost-benefit analysis of the use of TBT: the case for a treatment approach. Science of The Total Environment 258(1-2):5-19.

2. Adiana, G., Juahir, H., Joseph, B. and Shazili, N.A.M. 2017. Tracing the sources of lead (Pb) in Brunei Bay, Borneo by using integrated spectrometry ICP-MS and chemometric techniques. Marine Pollution Bulletin 123:232-240.

3. Ali, H. R., Mohd Ariffin, M., Sheikh, M. A., Shazili, N. A. M., Bakari, S. S. B. and Bachok, Z. 2014. Contamination of Diuron in coastal waters around Malaysian Peninsular. Marine Pollution Bulletin 85:287-291.

4. Ali, H. R., Mohd Ariffin, M., Sheikh, M. A., Shazili, N. A. M., Bakari, S. S. B. and Bachok, Z. 2015. Toxicology studies of Irgarol-1051 and its effects on fatty acid composition of Asian sea-bass, Lates calcarifer. Regional Studies in Marine Science 2:171-176.

5. Ansanelli, G., Manzo, S., Parella, L., Massanisso, P., Chiavarini, S., Di Landa, G., Ubaldi, C., Cannarsa, S. and Cremisini, C. 2017. Antifouling biocides (Irgarol, Diuron and dichlofluanid) along the Italian Tyrrhenian coast: Temporal, seasonal and spatial threats. Regional Studies in Marine Science 16:254-266.

6. Caquet, T., Roucaute, M., Mazzella, N., Delmas, F., Madigou, C., Farcy, E., \& Gabellec, R. 2013. Risk assessment of herbicides and booster biocides along estuarine continuums in the Bay of Vilaine area (Brittany, France). Environmental Science and Pollution Research, 20(2): 
651-666.

7. Chabukdhara, M. and Nema, A.K. 2012. Assessment of heavy metal contamination in Hindon River sediments: a chemometric and geochemical approach. Chemosphere 87:945-953.

8. Dafforn, K. A., Lewis, J. A. and Johnston, E. L. 2011. Antifouling strategies: History and regulation, ecological impacts and mitigation. Marine Pollution Bulletin 62(3):453-465.

9. Dupraz, V., Stachowski-Haberkorn, S., Ménard, D., Limon, G., Akcha, F., Budzinski, H.,Cedergreen, N., 2018. Combined effects of antifouling biocides on the growth of three marine microalgal species. Chemosphere 209: 801-814.

10. ECHA ECA (2017) Guidance on the biocidal products regulation volume IV environment-assessment and evaluation (parts $B+C)$ version 2.0.

11. European Commission. (2003). Technical Guidance Document on Risk Assessment (Part II), European Chemicals Bureau.

12. Evans, S. M., Birchenough, A. C. and Brancato, M. S. 2000. The TBT ban: Out of the frying pan into the fire? Marine Pollution Bulletin 40(3):204-211.

13. Fernandez, M. V. and Gardinali, P. R. 2016. Risk assessment of triazine herbicides in surface waters and bioaccumulation of Irgarol and M1 by submerged aquatic vegetation in Southeast Florida. Science of The Total Environment 541:1556-1571.

14. Gallucci, F., de Castro, I. B., Perina, F. C., de Souza Abessa, D. M. and de Paula Teixeira, A. 2015. Ecological effects of Irgarol 1051 and Diuron on a coastal meiobenthic community: A laboratory microcosm experiment. Ecological Indicators 58:21-31.

15. Girling, J. A., Thomas, K. V., Brooks, S. J., Smith, D. J., Shahsavari, E. and Ball, A. S. 2015. A macroalgal germling bioassay to assess biocide concentrations in marine waters. Marine Pollution Bulletin 91(1):82-86.

16. Hanapiah, M., Zulkifli, S. Z., Shahrun, M. S., Mohamat-Yusuff, F., Ismail, A., Harino, H. and Inoe, K. 2017. Concentration of antifoulant herbicide, Diuron in the vicinity of Port Klang, Malaysia. In Isu-isu terkini penyelidikan saintifik sains marin di Malaysia, Eds. Mohamed, C. A. R., Samsuddin, M. and Mohd Yatim, A. F., pp 35-38. Pusat Pengajian Sains Sekitaran dan Sumber Alam, Fakulti Sains \& Teknologi, Universiti Kebangsaan Malaysia, Malaysia.

17. Juahir, H., Ghazali,, A., Ismail, A., Mohamad, M., Hamzah, F.M., Sudianto, S., Lasim, M.L.M. and Shahriz, M.A. 2019. The assessment of Danau Kota Lake water quality using chemometrics approach. IOP Conference Series: Materials Science and Engineering 621:012019.

18. Kaonga, C. C., Takeda, K. and Sakugawa, H. 2015. Diuron, Irgarol 1051 and Fenitrothion contamination for a river passing through an agricultural and urban area in Higashi Hiroshima City, Japan. Science of The Total Environment 518-519:450-458.

19. Konstantinou, I. K. and Albanis, T. A. 2004. Worldwide occurrence and effects of antifouling booster biocides in the aquatic environment: a review. Environment International 30(2):235-248.

20. Kucuksezgin, F., Aydin-Onen, S., Gonul, L. T., Pazi, I. and Kocak, F. 2011. Assessment of organotin (butyltin species) contamination in marine biota from the Eastern Aegean Sea, Turkey. Marine Pollution Bulletin 62(9):1984-1988.

21. Macken, A., Giltrap, M., Foley, B., McGovern, E., McHugh, B. and Davoren, M. 2008. A model compound study: The ecotoxicological evaluation of five organic contaminants employing a battery of marine bioassays. Environmental Pollution 153(3):627-637.

22. Magnusson, M., Heimann, K., Ridd, M. and Negri, A. P. 2013. Pesticide contamination and phytotoxicity of sediment interstitial water to tropical benthic microalgae. Water Research 47(14):5211-5221.

23. Mukhtar, A., Mohamat-Yusuff, F., Zulkifli, S. Z., Harino, H., Ismail, A. and Inoue, K. 2019. Concentration of organotin and booster biocides in sediments of seagrass area from Sungai Pulai Estuary, South of Johor, Malaysia. Environments 6:26.

24. Omar, T.F.T, Aris, A. Z., Md. Yusoff, F. and Mustafa, S. 2018. Occurrence, distribution, and sources of emerging organic contaminants in tropical coastal sediments of anthropogenically impacted Klang River estuary, Malaysia. Marine Pollution Bulletin 131:284-293.

25. Omar, T. F. T., Aris, A. Z., Yusoff, F. M., \& Mustafa, S. 2019. Risk assessment of pharmaceutically active compounds (PhACs) in the Klang River estuary, Malaysia. Environmental Geochemistry and Health 41(1): 211-223.

26. Palma, P., Köck-Schulmeyer, M., Alvarenga, P., Ledo, L., Barbosa, I. R., De Alda, M. L., \& Barceló, D. 2014. Risk assessment of pesticides detected in surface water of the Alqueva reservoir (Guadiana basin, southern of Portugal). Science of the Total Environment, 488, $208-219$.

27. Park, M.S., Kim, Y.D., Kim, B.M., Kim, Y.J., Kim, J.K., Rhee, J.S., 2016a. Effects of antifouling biocides on molecular and biochemical defense system in the gill of the pacific oyster crassostrea gigas. PLoS One 11.

28. Park, K., Nikapitiya, C., Kim,W.-S., Kwak, T.-S., Kwak, I.-S., 2016b. Changes of exoskeleton surface roughness and expression of crucial participation genes for chitin formation and digestion in themud crab (Macrophthalmus japonicus) following the antifouling biocide Irgarol. Ecotoxicol. Environ. Saf. 132, 186-195.

29. Rameli, N. L. F. and Jaafar, M. 2014. Changes of coastline: A study case of Carey Island - Morib coast, Selangor, Malaysia. In The Malaysia - Japan model on technology partnership, Eds. Ab. Hamid, K., Ono, O., Bostamam, A. M. and Ling, A. P. A., pp $301-309$. International Proceeding 2013 of Malaysia - Japan Academic Scholar Conference, Springer, Tokyo. 
30. Shevalkar, M., Mishra, A. and Meenambiga, S. S. 2020. A review on invasive species in marine biofouling. Research Journal of Pharmacy and Technology 13(9):4517-4521.

31. Thomas, K. V., McHugh, M. and Waldock, M. 2002. Antifouling paint booster biocides in UK coastal waters: inputs, occurrence and environmental fate. Science of The Total Environment 293(1-3):117-127.

32. Tsunemasa, N. and Okamura, H. 2011. Effects of organotin alternative antifoulants on oyster embryo. Archives of Environmental Contamination and Toxicology 61:128-134.

33. US Environmental Protection Agency. 2011. Estimation program interface EPI, Suite, Version. Washington, DC, USA: Environmental Protection Agency, Office of Pollution Prevention and Toxic's.

34. Viana, J. L. M., dos Santos Diniz, M., Dos Santos, S. R. V., Verbinnen, R. T., Almeida, M. A. P., \& dos Santos Franco, T. C. R. 2020. Antifouling biocides as a continuous threat to the aquatic environment: Sources, temporal trends and ecological risk assessment in an impacted region of Brazil. Science of The Total Environment 730: 139026.

35. Wee, S. Y., \& Aris, A. Z. (2017). Ecological risk estimation of organophosphorus pesticides in riverine ecosystems. Chemosphere 188: 575581.

\section{Figures}

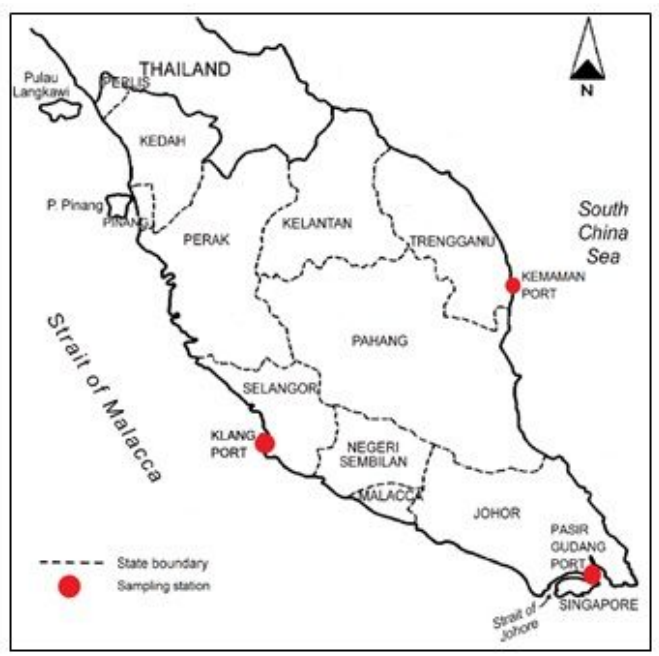

\section{Figure 1}

Sampling location at three major ports in peninsular Malaysia. Note: The designations employed and the presentation of the material on this map do not imply the expression of any opinion whatsoever on the part of Research Square concerning the legal status of any country, territory, city or area or of its authorities, or concerning the delimitation of its frontiers or boundaries. This map has been provided by the authors. 


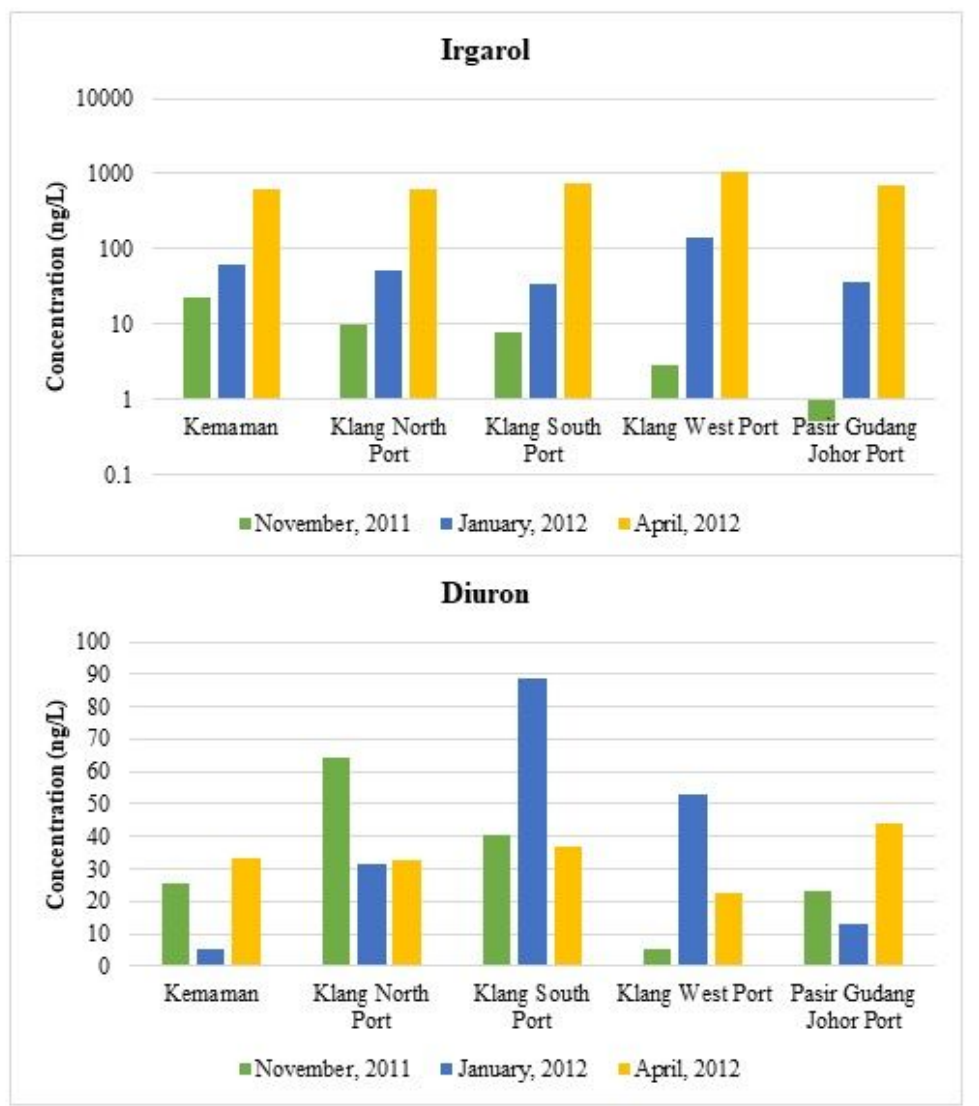

Figure 2

Distribution of Irgarol and Diuron in the seawater of major ports in Peninsular Malaysia.

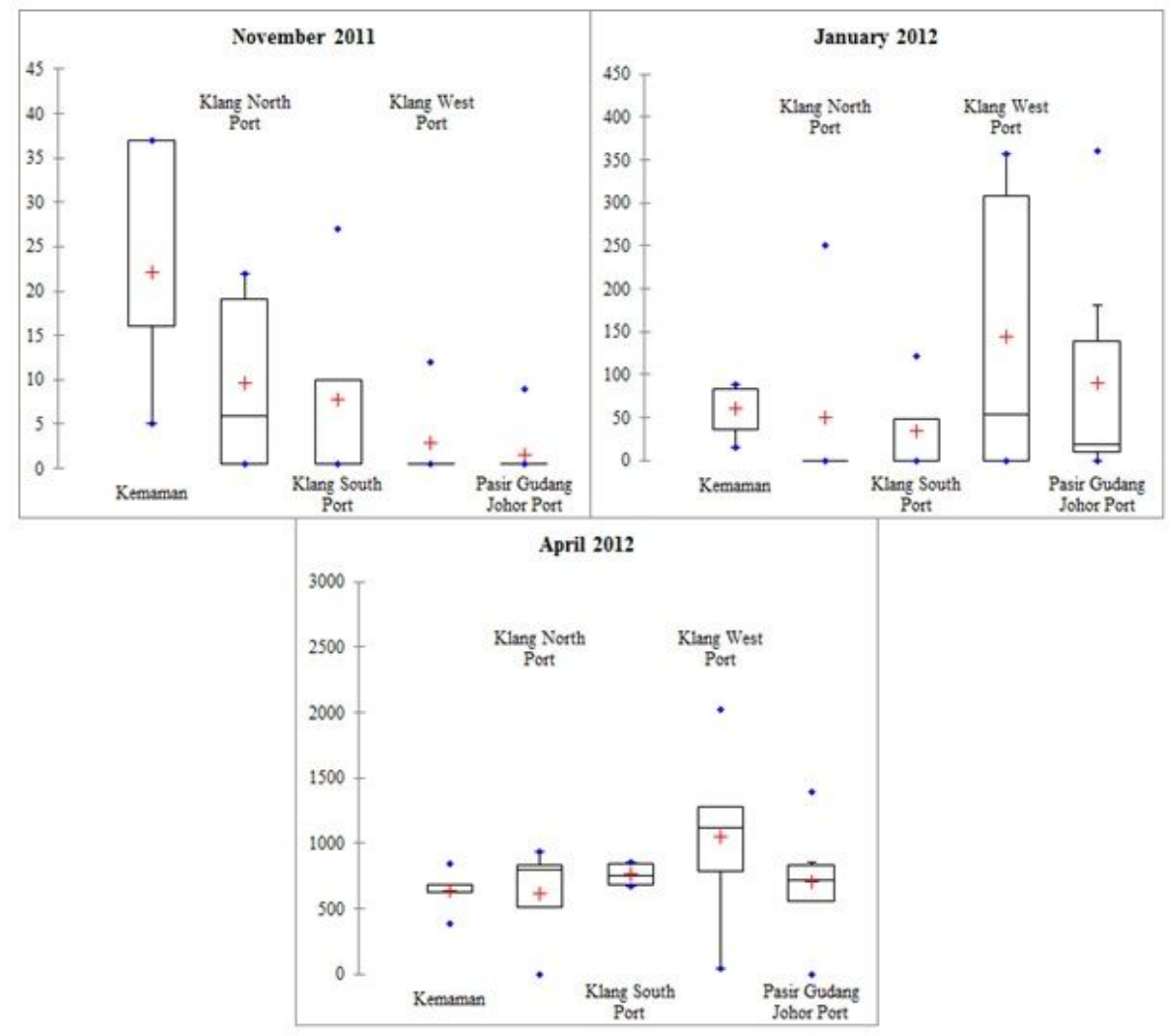

Figure 3 
Box and whisker plots of Irgarol spatial distribution throughout all sampling periods.

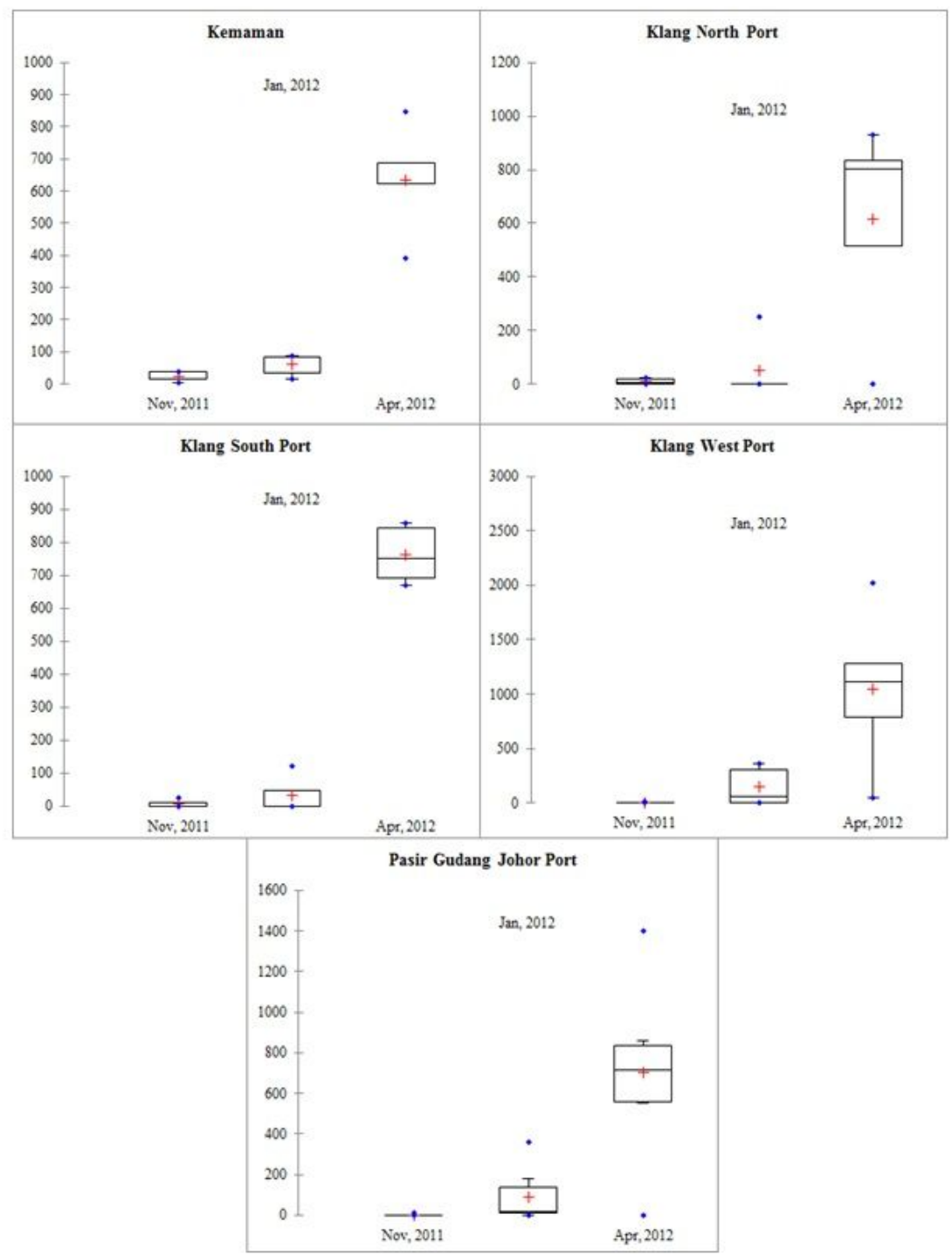

Figure 4

Box and whisker plots of Irgarol temporal distribution at all sampling areas.

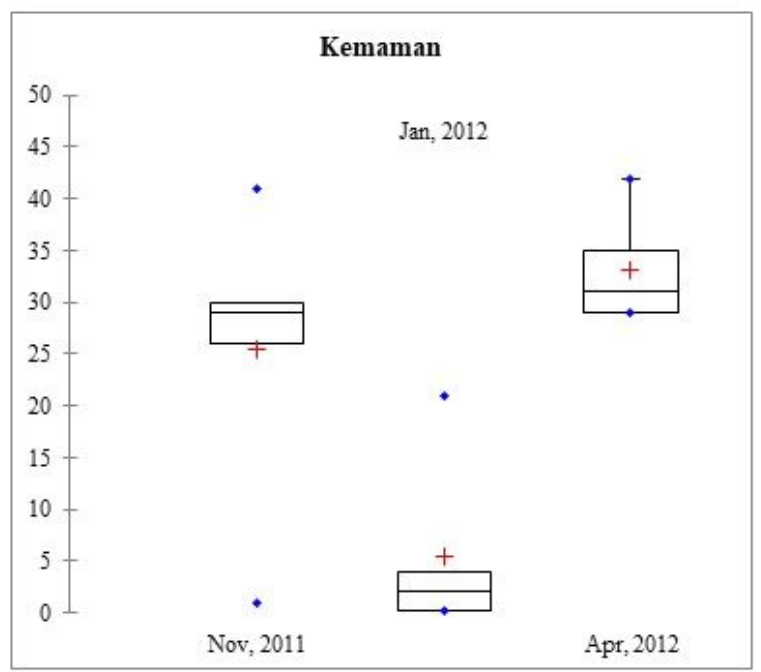

Figure 5

Page 12/13 
Box and whisker plots of Diuron temporal distribution at Kemaman Port.

November 2011

January 2012

April 2012

November 2011

January 2012

April 2012

Algae Daphnids Fish Algae Daphnids Fish Algae Daphnids Fish Algae Daphnids Fish Algae Daphnids Fish Algae Daphnids Fish

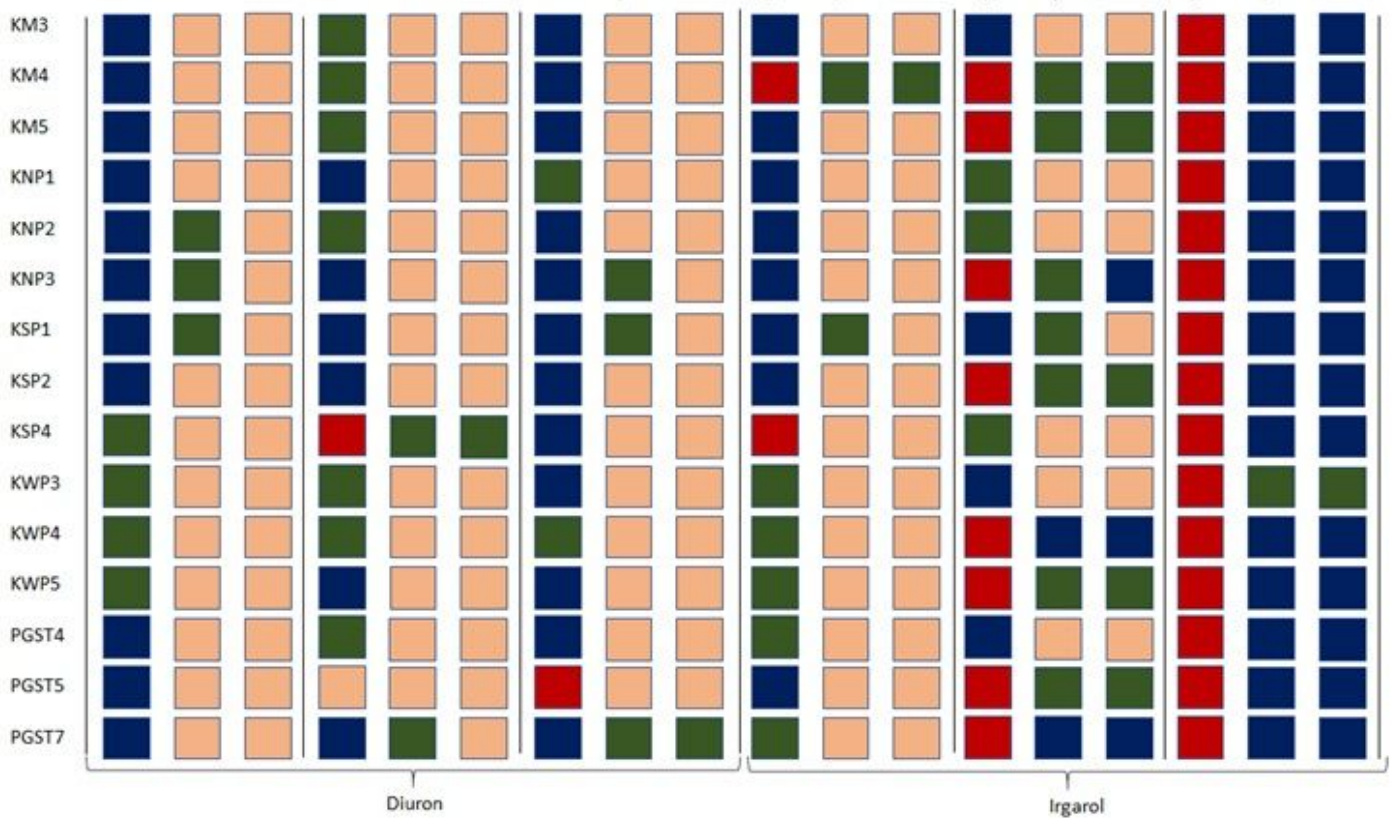

$\square$ Negligible risk

Low risk

Moderate risk

High risk

\section{Figure 6}

Risk assessment of Irgarol 1051 and Diuron from selected ports of peninsular Malaysia. 